\title{
The transformation of collective action in Latin America
}

\section{Manuel Antonio Garretón M.}

Department of Sociology

University of Chile

magarret@uchile.cl
We are witnessing the disappearance of the traditional paradigm that viewed the structural position as the determining factor in shaping collective action and social actors. Because of the structural and cultural changes that have occurred in the world and the region -the transformation of Latin America's weak national Statecentred industrial society and the break-up of the traditional relationships between State and society- collective action is tending to take shape mainly along four axes: political democratization; social democratization or the struggle against exclusion and for citizenship; the reconstruction and international reintegration of national economies or the reformulation of the economic development model, and the redefinition of a model of modernity. As a result, social actors are becoming less wedded to single causes, more concerned with sociocultural issues than politico-economic ones, and more focused on demands concerned with quality of life and inclusion than on projects of broader social change. 


\section{Analytical approaches}

For decades, collective action and social actors in the region were dominated by a theoretical and practical paradigm that closely matched the predominant paradigms of the social sciences throughout the world. What it affirmed was, firstly, that there was a unity or correspondence between structure and actor; secondly, that the structure prevailed over the actor, and thirdly, that there was a central axis constituted by structures and the processes arising from them, which acted as the underlying principle behind all collective action and the development of social actors.

Both theoretically and practically, in other words, the traditional paradigm for social actors and collective action gave precedence to the structural dimension. This was the "hard" component of society, while actors and collective action were the "soft" component.

There is a widespread conviction that this paradigm no longer matches today's reality. This is because, firstly, huge structural and cultural transformations have taken place, producing a different societal type. Meanwhile, new forms of social action and new actors have appeared, at the same time as the lines of action taken by traditional social actors have been changing. In the realm of analytical thinking about actors and forms of collective action, a number of milestones can be identified in the overthrow of the classical paradigm. ${ }^{1}$ From the point of view of social phenomena themselves, meanwhile, human rights movements and democratic movements under dictatorships, ethnic movements like those of Chiapas or the networks of social organizations and experiments with neighbourhood citizenship associations in Peru, to name some emblematic

This article is based on Cambios sociales, actores y acción colectiva (Garretón, 2001b). It draws heavily on material developed in other publications, particularly "Social movements and the process of democratization. A general framework" (Garretón, 1995b). Two recently published books (Garretón, 2000a and 2000b) recapitulate many of the works that we have drawn upon here.

${ }^{1}$ The most important and decisive is Alain Touraine's work on social actors and the political system. The first systematic formulation in Actores sociales y sistemas políticos en América Latina (Touraine, 1987) was further developed in Politica y sociedad en América Latina (Touraine, 1989). The same line of thinking was followed a decade earlier by Zermeño (1987) in México: una democracia utópica. El movimiento estudiantil del 68. examples, seem to us to have distanced themselves from what we have called the traditional paradigm of collective action, although they incorporate and redefine many of its elements, something that can be seen even more clearly in the Landless Workers Movement in Brazil.

In what follows, we shall attempt to schematize some of the analytical approaches that are helping to shape what may be the beginnings of a paradigm for actors and collective action in Latin America. ${ }^{2}$ The idea is to go beyond a universal type of structural determinism and to get past the notion of an abstract, essentialist correlation, defined once and for all, among politics, the economy, culture and society, i.e., the belief that a particular political or cultural form necessarily corresponds to a given economic system, or vice versa.

Thus, in a given society it is possible to discern levels or dimensions and spheres or ambits of social action. The levels or dimensions, which intertwine while remaining independent of one another, are: individual behaviour and the interpersonal relationships that define what are called "worlds of life", the organizational and institutional levels corresponding to the world of instrumentalities, and the historico-structural dimension, that of the projects and counter-projects determining what some term "historicity". ${ }^{3}$ As regards the spheres or ambits of action, these are the way the material needs of society are met, known as the economy; the formulas and institutions governing life in society, conflicts, stratification or hierarchization that determine the social structure or organization in a broad sense; the configuration of the power relationships

\footnotetext{
2 These ideas are dispersed around a number of the author's works, particularly "A new socio-historical 'problématique' and sociological perspective" (Garretón, 1998), Hacia una nueva era politica. Estudio sobre las democratizaciones (Garretón, 1995a) and "¿En qué sociedad vivi(re)mos? Tipos societales y desarrollo en el cambio de siglo" (Garretón, 1997a). The most recent formulation, from which some elements are drawn here, was Politica y sociedad entre dos épocas. América Latina en el cambio de siglo (Garretón, 2000a).

${ }^{3}$ We have redeveloped the categorization proposed almost three decades ago by Touraine (1973).
} 
concerned in the general running of society, known as politics; and models of ethics and knowledge and their application, conceptions of time and nature, symbolic representation and socialization, which are what we call culture. The system of determinations among these spheres and dimensions is flexible, changeable and historical.

Likewise, a given society is defined by the particular configuration of the relations between i) the State, ii) the political regime and parties, and iii) civil society or the social base. This historically delimited relationship is what makes it possible to talk of a sociopolitical matrix. The concept of a socio-political matrix, or matrix of constitution of society, refers to the relationship between the State, or the moment of society's unity and direction; the party political structure or system of representation, which is the moment of aggregation of general demands and political claims by social subjects and actors, and the socio-economic and cultural base of these, which constitutes the moment of participation and diversity in civil society. The institutional mediation among these elements is what we call the political regime.

The perspective described throws the weight of the analysis on actors, their constitution and interaction. When we speak of a subject-actor, ${ }^{4}$ we mean an embodiment (with a material or cultural basis) of individual or collective action that is actuated by principles of structuring, conservation or change in society, has a certain historical density, is defined in terms of identity, alterity and context and is involved in projects and counter-projects, and in which there is a permanently unresolved tension between the subject or vital constitutive principle of a given historical action and the particularity and materiality of the actor invoking it. Not everything that moves or acts in a society is an actor in the sociological sense of the term; the term agent might be used instead. Nor does what we call an actor always embody a high degree of historical density.

In a given society, then, a twofold matrix of actors can be identified. One is the socio-political matrix, the one that constitutes or gestates subjects and that refers to the relationships mediated by the political regime among the State, representation and the socio-economic and cultural base. The other is the matrix which shapes social actors, and in which each of these occupies a position in the dimensions or levels and in the spheres or ambits referred to earlier.

When we consider political processes of social struggle and change, the subject of social actors overlaps with that of social movements, defined as collective actions with a certain stability over time and with some degree of organization, undertaken with a view to changing or preserving society or some part of it. The idea of the Social Movement tends to oscillate between two poles: the immediate response to a particular situation or problem, and the embodiment of the sense of history and social change. From our perspective, the two poles can be seen as two dimensions of social movements. On the one hand, the Social Movement (upper case, singular) oriented towards the historico-cultural level of a given society and defining its central conflict. On the other, social movements (lower case, plural), concrete actors that move in the worlds of life and instrumentalities, whether organizational or institutional, and that are oriented towards specific goals and have problematic relationships, whose exact nature depends on the particular society and point in time, with the Central Social Movement. Social movements are one type of collective action but not the only one, and they have to be distinguished from at least two other forms of collective action that are important in societies in flux, namely demands and mobilizations. ${ }^{5}$

\footnotetext{
${ }^{4}$ Regarding the subject-actor, see Touraine (1984 and 2000). See also Dubet and Wieworka (1995).
} 


\section{II}

\section{Collective action in the traditional matrix}

In general terms, we can say that the Latin American socio-political matrix, for which we will use the terms "traditional", "politico-centric" and "national-popular" without distinction, ${ }^{6}$ and which prevailed from the 1930s until the 1970s with variations by period and by country, was created from the fusion of different processes: development, modernization, social integration and national autonomy. Any collective action was cut across by these four dimensions and all the different conflicts reflected these fusions.

In typico-ideal terms, the main characteristic of the national-popular matrix was the fusion among its components, i.e., the State, political parties and social actors. This meant that each individual component had little autonomy, with two or three of them intermingling while the rest were subordinated or suppressed. The particular combination among them depended on historical factors and varied from country to country. In any event, the favoured form of collective action was politics, and the weakest part of the matrix was the institutional link among its components, i.e., the political regime, whence the fluctuations or repeated cycles from democracy to authoritarianism and back again.

In this traditional matrix, the State played a referential role for all collective actions, be they development, social mobility and mobilization, redistribution or the integration of disadvantaged sections of society. But it was a State that had little autonomy from society and that was the focal point for all pressures and demands, whether internal or external. This intermingling of State and society meant that politics played a central role; but other than in exceptional cases, it was a politics of mobilization more than of representation, and representative institutions were generally the weakest part of the matrix.

It can be said, again in schematic and typico-ideal terms, that alongside the traditional socio-political matrix there was a central social actor that may be defined as the National-Popular Movement, which brought together the different social movements, despite their peculiarities. This means that every one of the particular social movements was at the same time, and to differing degrees, developmentalist, modernizing, nationalist and social change-oriented, and identified itself as part of the "people". The "people" was regarded as the only subject of history. The paradigmatic social movement or actor of the National-Popular Movement was usually the workers' movement, but at different times this leadership was called into question, and as a result other actors such as peasants, students or party vanguards were drawn in instead.

Thus, the main characteristics of this social actor or Central Social Movement were, firstly, the combination of a very strong symbolic dimension oriented towards broad social change with a dimension of very concrete demands. This meant the implicit or explicit assumption of the revolutionary approach, even when the actual movements concerned were very "reformist". The second characteristic was the way the State was looked to as the interlocutor of social demands and as the locus of power over society. This meant an omnipresent and complex relationship between the social movement and politics, involving perhaps complete subordination to parties, the manipulation of parties, or a more independent style of action. Thus, the weakness of the social movements' structural base was compensated for by ideology and politics.

\footnotetext{
${ }^{6}$ Concerning the term "national-popular", see Germani (1965) and Touraine (1989). We shall take some of the characterizations used in the latter work. The term "State-centric matrix" is found in
}

Cavarozzi (1996) and my own definition in Garretón (1995a and 1995b) and elsewhere.

THE TRANSFORMATION OF COLLECTIVE ACTION IN LATIN AMERICA • MANUEL ANTONIO GARRETÓN M. 


\section{III}

\section{The dismantling of the national- popular matrix}

The effort made by the military regimes of the 1960s and 1970 s to dismantle the traditional or politico-centric matrix, and certain institutional or structural transformations that also took place in other countries in the $1980 \mathrm{~s}$ without this type of authoritarianism, ${ }^{7}$ had some profound consequences for social actors and forms of collective action.

On the one hand, there are two meanings intertwined in the action of any particular social movement or actor under authoritarian systems. One is the reconstruction of the social fabric destroyed by authoritarianism and economic reforms. ${ }^{8}$ The other is the orientation of action, in the case of authoritarian regimes, towards the ending of these regimes, which politicizes all sectoral demands that are not specifically political to start with.

On the other hand, the repressive nature of authoritarian or military regimes, and the effort to dismantle the developmentalist State as a whole, which also took place in cases where there was no military regime, have meant that expectations of the State and links with politics have been changing dramatically for particular social actors, becoming more autonomous, more symbolic and more oriented towards identity and self-reference than towards instrumentality or protest. ${ }^{9}$

During the most repressive stage in the early days of authoritarianism, the main orientation of any collective action tended to be self-defence and survival; i.e., the central issue is life and human rights. ${ }^{10}$ When the authoritarian or military regime showed its more foundational aspect, movements diversified in different spheres of society and became more oriented towards cultural or social issues than economic or political ones. Lastly, when a regime began to break up and it seemed a real possibility that it would come to an end, social actors tended to become oriented towards politics and towards an institutional transition formula that subsumed and took up all the different manifestations of collective action that had gone before.

Where particular social movements were concerned, the authoritarian effort to change the role of the State, and the changes that took place in the economy and in society, transformed the spaces in which these were constituted, chiefly by weakening their institutional and structural underpinnings through repression, marginalization and the informalization of the economy. Instead of organized movements, most collective action during dictatorships came from social mobilizations that tended to emphasize their symbolic dimension more than the aspects of protest or instrumentality. The symbolic leadership role achieved by the Human Rights Movement is significant in this respect. It was the germ of what we might call the Central Social Movement of the period during which the national-popular matrix was being broken up under authoritarianism: the Democratic Movement.

\footnotetext{
${ }^{7}$ Concerning authoritarianisms and military regimes, see the now classic The New Authoritarianism in Latin America (Collier, ed., 1979) and the works of O'Donnell (1999) in his anthology Contrapuntos. For a general discussion of socio-economic changes inspired by neoliberalism, see Smith, Acuña and Gamarra (1994). ${ }^{8}$ Concerning the resurgence of civil society under authoritarianism, see Nun (1989). See also the collective works: Eckstein, coord. (2001c), Escobar and Alvarez, eds. (1992) and Slater, ed. (1985).
}

\footnotetext{
${ }^{9}$ For the meaning and development of social movements under military regimes, see Garretón (2001a). In the same volume, see also the articles of Eckstein (2001b), Moreira Alves (2001), Navarro (2001) and Levine and Mainwaring (2001). Regarding human rights movements and other types of resistance to authoritarianism, see the third part of Corradi, Weiss and Garretón, eds. (1992).

${ }^{10}$ Jelin and Herschberg, eds. (1995).
} 


\section{IV}

\section{Globalization and the transformation of modern society}

Two phenomena have significantly changed the issues for collective action in today's world.

One of them, known as globalization, has had a number of consequences insofar as it has penetrated societies or segments of them economically (markets) and in the field of communications (media, information, real and virtual networks, information technology) and cut across the independent decision-making of national States. ${ }^{11}$ One of these consequences is the disintegration of the traditional actors associated with the national State-centred industrialized society model. Another, with its own dynamics over and above globalization, is the explosion of adscriptive or communitarian identities based on sex, age, religion as revealed truth and not as an option, a non-State nation, an ethnic group, a region, etc. A third are the new forms of exclusion that have affected masses of people by establishing a purely passive or media-based link between them and globalization. Lastly, there is the emergence of globalized actors, the anti-globalization movements, which in turn confront the de facto transnational powers.

Meanwhile, the societal type that has predominated in recent centuries is being fundamentally changed all over the world, and in Latin America with some special characteristics that we shall refer to. This change can be summed up as the phenomenon of amalgamation between the basic societal type that was the reference point from the nineteenth century onward, the industrial society of the national State, and another societal type, the globalized post-industrial society. ${ }^{12}$

The reference type of society in respect of which countries could be more or less advanced, the industrial

\footnotetext{
${ }^{11}$ The widest-ranging work on this subject is that of Castells (1997). For a critical Latin American perspective, see Chonchol (2000), Flores Olea and Mariña (1999), García Canclini (1999) and Garretón, ed. (1999).

${ }^{12}$ There is a large literature dealing with the character of society and its impact on forms of collective action. For the purposes of this work, particular mention should be made of Castells (1997), Touraine (1997), Dubet and Martuccelli (1998) and Melucci (1996). For the more traditional view of social classes, see Wright (1997). My own ideas are to be found in Garretón (2000b).
}

society of the national State, had two fundamental axes: one was labour and production, the other was the national State, i.e., politics. As a result, social actors in this type of society were mainly actors associated with the world of work or production, i.e., having some relation with social classes and, at the same time, with the world of politics in the form of political parties or leaderships. The combination of the two is what we have called social movements.

In the case of Latin America, which was defined less by a consolidated industrial structure and national State than by processes of social integration and of industrialization and the construction of national States, the organization of society and thus the emergence of social actors as well was based more on politics -be it of an autocratic nature, or based on patronage or a party system- than on work or production.

The new type of society, which we could term globalized post-industrial society and which only exists as a principle or as a societal type in combination with the older type, is based primarily on consumption and information and communication. By contrast with the industrial State societal type, there is no political system implicit in its definition.

Around the basic axes of this societal model -consumption and information and communicationnew types of social actors are coming into being, although of course they are intermingled or coexist with transformed actors from the industrial State model of society. Firstly, there are publics and networks of different kinds, which may be more or less structured, specific or general, but which are characterized by the lack of a strong, stable organizational density. Secondly, there are actors with greater organizational density such as non-governmental organizations (NGOs), which also constitute national and international networks. Thirdly, there are identity actors, particularly those whose main identity construction principle tends to be adscriptive and not acquisitive. Lastly, there are the de facto powers, i.e., bodies or actors that process the decisions corresponding to a political regime, regardless of the democratic rules. These may be extra-institutional, as in the case of local or transnational economic groupings, 
corruption and drug trafficking, insurrectionary and paramilitary groups, foreign powers, transnational corporate organizations or the communications media. But there are also institutional actors with de jure powers that break away to assume political powers beyond those they can legitimately exercise, examples being international bodies, presidents ("hyperpresidentialism"), legal authorities, parliaments, constitutional courts and, in many cases, the armed forces.

All this is resulting in a transformation of the principles of collective and individual action. Despite the weakness of the industrial economic structure, the reference principles of actors in the traditional society that we have known and to which our generation in Latin America belongs are the State and the polis structured in the State. The reference principles of actors in the globalized post-industrial society are issues that go beyond the bounds of the polis or the national State (peace, the environment, globalist or holistic ideologies, gender). For identity actors, the main reference point is the social category to which they belong (they feel themselves to be young or women, Indian, elderly, natives of such and such a region, etc., rather than nationals of a country, or followers of an ideology, or performers of some function, or members of a profession).

It is true that Latin America always experienced Western industrial modernity of the national State in a fitful way, and that this never became consolidated as the organizing rationality of these societies. But it is also true that this modernity was a reference point in our countries' history in the last century and that it was experienced in an ambiguous way and in composition with other models of modernity. All this makes the upsurge of the new societal type in our societies more problematic.

Examination of the new manifestations of collective action in Chiapas or Villa El Salvador in Peru, peasant movements linked with drug trafficking or more traditional struggles for land, ethnic and gender movements, mobilizations to protest against the economic model, the new expressions of student movements and so on shows that all of these share features of both models of modernity, combined with the collective memories of those involved.

\section{The changing socio-political matrix}

\section{in Latin America}

Alongside the transformations resulting from globalization, in which Latin American societies are participating with difficulty and on a basis of dependency, subject to external domination strategies and to the dynamics of a new societal type that is amalgamating with the old one, both of them poorly rooted in these societies, there have also been profound changes in different dimensions, which these countries have experienced to differing degrees and in differing circumstances. ${ }^{13}$

The first change has been the arrival and relative consolidation of politico-institutional systems that are tending to replace the dictatorships, civil wars and

\footnotetext{
${ }^{13}$ For a general discussion of the issues faced by Latin America in the 1990s, see Reyna, comp. (1995) and Smith (1995), among others. For another viewpoint, see Sosa (1996).
}

revolutionary methods of previous decades. The second is the running down of the "inward development" model, whereby the State played a leading role in industrialization, and its replacement by formulas that give priority to the role of the private sector and to participation in a globalized economy dominated by transnational market forces. The third is the transformation of the social structure, with rising poverty, inequality, marginalization and insecurity of employment structures. Lastly, the fourth change is the crisis of the traditional forms of modernization and United States mass culture prevailing among ruling elites, and the recognition and development of homegrown and hybrid forms of modernity.

Between them, these processes have led to the breakdown and disintegration of the traditional or "national-popular" matrix. It was this matrix and its type of State that was being attacked, of course, both 
by the revolutionary movements of the 1960 s, which criticized its mesocratic aspect and inability to respond to popular interests, and by the military regimes that began in Latin America during those years. In turn, the democratic transitions of the 1980s and 1990s coincided with the realization that there was a gap where the old matrix had been, as military authoritarianism had broken it up without creating another stable, coherent configuration for State-society relations in its place. This gap has tended to be filled by different substitutes that have prevented the components of the matrix (State, political regime and actors, social actors and civil society) from strengthening or achieving autonomy or complementarity, and that have sought to replace or do away with one or another of them.

Three major tendencies -sometimes overlapping, sometimes intermingled, sometimes in a state of tension and struggle for partial hegemony among themselvesare trying to replace the matrix that is breaking up. There is neoliberalism, an effort to deny politics on the basis of a distorted, unilateral view of modernization expressed in an instrumental policy which replaces collective action with technocratic reasoning and in which the logic of the market seems to leave no room for any other aspect of society. This tendency has been accompanied lately by a view of politics that has helped to depoliticize society yet further by pronouncing that "resolving people's concrete problems" is its sole purpose.

Another tendency, which is a reaction to the above and to globalization, is represented by what is also a critical view of the State and politics, but one that has come out of civil society and that calls for this society to be strengthened, be it through the principles of citizenship, participation, empowerment or the different conceptions of social capital, or by invoking identity and community principles. ${ }^{14}$

Between these two positions -which are opposed to one another but which both tend to weaken the

${ }^{14}$ In relation to citizenship and participation, see ECLAC (2000b). Regarding social capital, see Portes (1998) and Durston (2000). Regarding identities, see ILADES (1996). legitimacy of the State and politics, the one by deeming them unnecessary and inefficient, the other by considering them elitist and unresponsive to new social demands and fields of action- there is the more institutionalist view that the role of the State and representative democracy should be strengthened to prevent society being destroyed by the market, de facto powers or the particularism of identity and corporate demands.

The gaps left by these three tendencies, each of which is incapable of constructing a new socio-political matrix, may leave room for the resurgence of nostalgia for populism, patronage, corporativism and partisanship and, in cases of extreme breakdown, neo-populist autocracies, but this time without the appeal of grand ideological projects or mobilizations capable of drawing in large sections of society. This type of nostalgia appears in rather fragmentary forms, often in parallel with elements of anomie, apathy or atomization, and in some cases of crime, as in the cases of drug trafficking and corruption.

Thus, the fundamental question is whether or not, looking beyond democratic transitions or the shift to an economic model based on transnationalized market forces, we are seeing the emergence of a new type of society, i.e., of a new socio-political matrix. The most likely thing is that the countries will follow different paths, experiencing in one way or another the major tendencies referred to. Although there is a risk of permanent breakdown or instability and crisis without a clear new standard for the relationship among the State, politics and society, it is also possible that some laborious headway may be made towards a new matrix of an open type, i.e., one that is characterized by the autonomy and complementary tension of its components, combined with subordinate elements of the traditional matrix now breaking up, and that reshapes traditional politics and cultural orientations.

The outcome of these processes cannot yet be predicted. It seems that the formal political framework will be democratic, but there is no guarantee of how important this will be in relation to de facto transnational and local powers. 


\section{VI}

\section{The new axes of collective action}

Where collective action is concerned, the structural and cultural changes now affecting both the Latin American societal type and the traditional relationship between the State and society are resulting in a twofold paradigm shift. Firstly, collective action is being organized and social actors shaped less in terms of the structural position of individuals and groups and more in terms of the directional axes of this action. Secondly, the four axes of action that we shall define are not integrated into a single societal project that orders them among themselves and defines their relations, priorities and determinations in structural terms, but rather each of them has an equally high priority, has its own dynamic and defines actors who are not necessarily the same as in the other axes, as was the case with the fusion of the different orientations in the national-popular movement or in the democratic movement that followed it.

\section{Political democratization}

In recent decades, there have been three types of democratization processes, setting out from different authoritarian situations. The first type is foundational, i.e., the creation of a democratic regime in countries where no democratic system as such has ever existed, starting out from oligarchic or hereditary regimes or from situations of civil war, insurrection or revolution, this being the case mainly in Central America. The second type is the transition to democracy from formal military or civil dictatorships, chiefly in the countries of the Southern Cone. The third is the reform type, i.e., the extension of democratic institutions by the authorities themselves under pressure from society and the political opposition, as in the case of Mexico. ${ }^{15}$

The foundation of democracy, by its very nature, requires the presence of actors and institutions from within the country or elsewhere who can mediate between the sectors in conflict, and the transformation of these into political actors. Transitions do not operate

\footnotetext{
${ }^{15}$ In relation to transitions and democratization, see among many others Barba, Barros and Hurtado, comps. (1991), and for an updated assessment and review see Hartlyn (2000). My own views can be found in Garretón (1995a and 1997b) and in "Política y sociedad entre dos épocas" (Garretón, 2000a). The assessment presented here is based on the last-named work.
}

by overthrowing the old order but through negotiations within institutional frameworks, but their defining feature is that power changes hands, and they give a central place to political parties as key actors and to corporative groups that apply pressure to safeguard their interests in the process of ending dictatorships and in the regimes that will succeed them, subordinating the social movements that were important in triggering the transition. Reforms do not necessarily involve power changing hands, and it is hard to say when they are really complete. The interplay of political parties and actors at the highest level is essential to them, although it is civil society movements that keep up the pressure to prevent reform from losing momentum.

While it is true that each form of democratization has different implications for forms of social action and gives pride of place to particular social actors, it is possible to lay down a general rule, to which each case and subcase will bring its special features.

If we identified the National-Popular Movement as the subject or central constitutive principle of the traditional or politico-centric matrix, it can be said that the construction of political democracies meant that this shifted towards the Democratic Movement, i.e., towards a central actor or movement that, for the first time, was oriented not towards the specific interests of a social sector or towards radical, comprehensive social change, but rather towards a change in political regime. In such situations, authoritarian governments become the most important principle of opposition, and the ending of the regime and the introduction of democracy become the main goal of collective action. With this change, the Social Movement gains in instrumental terms, but the price that has to be paid is the subordination of particular demands to political goals. At the same time, leadership passes to political actors, chiefly parties. Negotiations and consensus at the level of leaderships and elites tend to replace social mobilizations during the democratic transition and the consolidation process.

In this way, political democratization tends to separate out collective action into three logics that transverse all particular social actors. One of these is the political logic oriented towards the establishment of a consolidated democracy as the precondition for any other type of demand. Another is the particular logic 
of each of the actors, whose objectives are concrete benefits in the form of social democratization as a precondition for actively supporting the new democratic regime. The final logic criticizes the inadequacy of institutional change and conceives of democracy as a deeper social change that extends to other dimensions of society. This logic, which plays a subordinate part during political democratization, is expressed subsequently through the other axes of collective action that we examine below.

The existence of ethical issues that remained unresolved during transitions or democratization, particularly violations of human rights under dictatorships, meant that human rights movements retained an important role at the beginning of the new democracies. But severe constraints were placed on them by the existence of other enclaves of authoritarianism, whether institutional or holding de facto power (the military, business, paramilitary groups), and particularly by the risks of a return to authoritarianism and of economic crises. This gave political actors, in government and in opposition, key roles in social action, and meant they could subordinate other actors' principles of action to their own logic. In turn, the tasks associated with the consolidation process initially gave the foremost place to the needs and requirements of economic adjustment and stability, discouraging collective action that was believed to jeopardize these. As a result, there was some tendency for social movements to break up and become inactive. But an even more important factor is that when the postdictatorial regimes were established, social movements were left without a compelling central principle.

The results of political democratization must be viewed as positive where transitions and the consolidation of post-authoritarian regimes are concerned, and as unsatisfactory, in general, as regards the democratic depth and quality of these regimes.

The fact is that the democratic regimes that have succeeded military or civilian dictatorships, while they are well consolidated, are either incomplete or weak. In other words, they are regimes that in some cases are basically democratic but still retain remnants of the old regime, what we have termed authoritarian enclaves. These are institutional (constitutions, captive legislative systems, etc.), ethico-symbolic (unresolved problems of truth and justice concerning crimes and human rights violations committed by the State), actoral (groups that seek to return to the old regime or do not follow the democratic rules fully) and cultural (inherited attitudes and behaviour that hinder citizen and democratic participation). In other cases, recomposition of the system of representation in the democratic regime is a work in progress. Lastly, there is a group of countries in which the political system as a whole is breaking down to some degree, or in which those who hold the real power do not submit to the institutional ground rules or the citizenry has failed to constitute itself as such, making their democracies more or less irrelevant in the performance of the tasks that any regime has to deal with.

It is obvious that the issue of democratic quality and consolidation will give rise to a configuration of actors in which there is tension between those who are more politics- and State-oriented, whose concern will be for institutional reforms and the modernization of the State, and those who link together social and citizenship demands characteristic of the second axis that we referred to. Alongside its own quest for social integration, the Zapatist National Liberation Army (EZLN) in Mexico included the holding of clean elections among its earliest demands, while the indigenous movement in Ecuador also linked its own particular demands to a change of government.

\section{Social democratization}

The second axis around which collective actions and social actors are constituted is what may be termed social democratization. Among the different meanings of this concept, two are relevant for our purposes. The first is the redefinition of citizenship. The second is the surmounting of poverty and exclusion. ${ }^{16}$

We are now seeing unprecedented growth in appreciation of the citizenship dimension, as manifested in the fact that virtually all demands and claims are made in the name of citizenship or citizen rights. It is true that many of these are confused with what are in fact social demands, so that the use made of the concept by NGOS and international organizations is sometimes mistaken and sometimes loses its specific sense of equal rights for individuals (citizenship) vis-à-vis the State polity which are guaranteed by particular institutions, and to secure which a body of citizens possessing such rights (citizenry) is organized.

\footnotetext{
${ }^{16}$ For excellent analyses of these aspects, particularly exclusion, see Filgueira (2001) and ECLAC (2000a and 2000b). Concerning citizenship, see ECLAC (2000b), but also Hengstenberg, Kohut and Maihold, eds. (1999) and Jelin and Herschberg, eds. (1995). A very good national case study is found in López (1997). Concerning the weakening of civil citizenship, which we shall mention later on, see O’Donnell (2001).
} 
Appreciation of citizenship stands in contrast, however, to the weakening of the institutions that traditionally served to express it, particularly in the field of civil rights.

There are actors who operate in this field of traditional demands, i.e., actors threatened by what they see as the loss of rights won in historical struggles because of the weakening role of the State and the institutions that guaranteed them. There are others whose struggles are against discrimination, i.e., whose aim is the extension of rights already enjoyed by integrated citizens to members of particular categories (gender, socio-economic level, ethnic group, region, etc.). In addition, though, in those fields of traditional citizenship where institutions exist, the issue now is one not just of access to or the coverage of particular citizen rights, but of the quality of the good being aspired to. This obviously depends on the nature of the group claiming it, which means that a universal right cannot have the same content for everyone (the demand for education or health care, for example). This limits the capacity for action, as the citizenry dimension is particularized.

Again, if it is citizenship that provides the basis for recognition and affirmation of a possessor of rights vis-à-vis a given authority, and if in the past that authority was usually the State, fields or spaces are now emerging in which people are doing something equivalent or analogous with citizenship. They want to exercise rights, but the authority from which they have to be won is no longer necessarily the State, or is only partly the State. One example are rights relating to the communications media, where people do not want the parameters of choice set for them during the large amount of their lifespan that they spend watching television, and would like to have some kind of citizenship. The environment is another sphere that has seen the emergence of power relationships, rights and a field of citizenship that do not relate exclusively to the State. The same is true of membership of more than one national community, as happens in border areas or when mass migration occurs.

Lastly, when citizenship is being redefined in this way, there are demands and struggles for rights that entail a revolution in the traditional principle of human or citizen rights, or the rights of the republican model. Two different dimensions come into play here. One is that of rights which are claimed in the name of an identity, and which cannot be extended to other categories (the rights of women, the young and the disabled), but whose possessors are still individuals.
The other dimension is that of rights whose possessors are not individuals but groups, as with the rights of indigenous peoples, and this is a reinvention of the concept of citizenship (Stavenhagen, 2000).

For all these new fields of citizenship, institutions either do not exist or are embryonic and partial. What there is in the place of institutions to regulate the rights and duties of those concerned, then, is a general demand where the adversary and the referent are diffuse.

The other face of social democratization is the effort to surmount the new forms of social exclusion deriving from the current socio-economic model.

In the period previous to military authoritarianism and "structural adjustments", forms of integration were associated with industrialization and urbanization, with the expansion of State services and with political mobilization. In each of these fields, it was possible to detect an inclusion-exclusion dialectic and a process in which excluded sectors organized to achieve integration.

Today, excluded sectors are separated from society, maintaining with it some form of purely symbolic relationship that appears to have nothing to do with the economy or politics. At the same time, they are fragmented and have no connection among themselves, which makes any collective action very much harder. Thus, besides the destructuring of political communities resulting from globalization and the explosion of identities unconnected with national States, a huge mass of people has been expelled from the little that remains of those political communities. The question is not just what economic model can integrate the excluded sector in the space of a generation, but what type of political system is capable of providing it with real, active participation without shattering and without resorting to manipulation or populism.

The incorporation of the excluded part of society, which in some countries may exceed $60 \%$ of the population, is now being considered in new terms: the excluded section is no longer an actor situated within a context of conflict with other social actors but, simply and tragically, a sector that it is believed can be discarded from society, that there is no need even to exploit.

An overview of the collective actions of the 1990s shows that the citizenship-exclusion axis has been one of the main constituents of action by the region's social actors, being a factor both in ethnic movements and in the new characteristics of settler movements, the demands of poor urban sectors, neighbourhood organizations and local or regional movements, youth 
movements and mobilizations against company closures.

In general, it is around these issues of social democratization that the more political actors, such as parties moving towards what they call "people's concerns", or the more economic ones, such as sectors affected by economic crises and job losses, are repositioning themselves. ${ }^{17}$

\section{The reconstruction of national economies and their re-entry into the world economy}

The consequences of the transformation of the development model are the third axis of collective action. ${ }^{18}$ The transformation of the old "inward" development model based on the State's action as an agent of development and the re-entry of national economies into the world economic globalization process on the basis of transnational market forces meant that the economy became less dependent on politics than it was under the inward development model, but left society entirely at the mercy of national and, particularly, transnational economic powers.

This transformation was effected in the main through adjustment or structural reforms of a neoliberal type. But neoliberalism has brought about only limited participation in the international economy and has resulted in certain sectors becoming newly dependent, so that a dual type of society is once again being created and the search for an alternative development model is under way. To put it another way, the neoliberal model served only as a break with the past and proved a total failure at establishing stable, self-sustained development.

Where issues associated with social actors are concerned, the new economic model that is taking hold worldwide has a number of consequences. ${ }^{19}$

On the one hand, the prevailing economic model tends to be intrinsically disintegrative at the national level and partially integrative, although obviously asymmetrical, at the supranational level. This implies the break-up of traditional social actors linked to the world of work and the State and makes it very difficult

\footnotetext{
17 Escobar and Alvarez, eds. (1992), Eckstein, coord. (2001c), Calderón and Reyna (1995).

${ }^{18}$ Regarding economic transformations, see Smith, Acuña and Gamarra, eds. (1994), Ffrench-Davis (2000) and ECLAC (1992).

${ }^{19}$ Concerning the structural basis of social transformations, see Filgueira (2001). For their impact on social movements in the 1980s and 1990s, see Calderón, ed. (1986), Colegio de México (1994), Eckstein (2001a) and Stavenhagen (1995).
}

for the new issues referred to (the environment, gender, urban security, local and regional democracy within a country, etc.) and the new social categories (age, gender and ethnic groups, different publics associated with consumption and communication) to become politically representable social actors. This breakdown of social actors is coinciding with the weakening of the State's capacity for action, which is a basic referent for collective action in Latin American society.

As a result, defensive struggles have come to predominate, sometimes in the form of savage uprisings, sometimes through the mobilization of traditional actors linked to the State, in defence of their previous gains (public-sector employees, teachers or workers in formerly State-owned companies). Students are generally more concerned to defend course interests threatened by the privatization of higher education than to bring about deeper reform in the education and university system. Workers' struggles and demands aim to mitigate the effects of the model on their standard of living, employment and job quality, with the State invariably being called upon to intervene, and are not anticapitalist positions as such. Meanwhile, there is a double movement among business actors, who are split between the winners and losers from economic liberalization and globalization: the latter opt for defensive corporativization of a nationalist type, while the former seek internationalization of rules of action and a more aggressive internal dynamic, but without succeeding in turning themselves into a governing class.

\section{The reformulation of modernity}

The fourth axis, which can be seen as a synthesis of the others, but which has its own dynamic and specificity as a source of collective action, is the struggle over the model of modernity, identities and cultural diversity. Like all the others, of course, it is overlaid by struggles for citizenship. ${ }^{20}$

Modernity is the way a society constitutes its individual and collective subjects. The absence of modernity is the absence of subjects. It needs to be remembered that, sociologically, we must speak not of "modernity", but of "modernities". Each society has its own modernity. The different models of modernity

\footnotetext{
${ }^{20}$ For a general analysis of the subject of modernity, see Touraine (1992), ILADES (1996), García Canclini (1980), Garretón, ed. (1999) and Bayardo and Lacarrieu (1999). My own views can be found in Garretón (1994) and, more recently, in "La sociedad en que vivi(re)mos" (Garretón, 2000b).
} 
are always a problematic combination of scientific and technological rationality, the expressive and subjective dimension (feelings, emotions, impulses), identities and the collective historical memory.

The particular form taken by Latin American modernity, based around what we have termed the national-popular matrix, has gone into crisis. What has been proposed in response to this is simply to copy the model of modernity identified with specific modernization processes in the developed countries, but with a special emphasis on the mass consumption and culture model of the United States. Neoliberalism and the so-called "new authoritarianisms", most of them military, identified their own historical project with modernity. The democratic transitions of recent years corrected only the political dimension, on which they put a democratic stamp.

In opposition to this model, there have arisen visions of Latin American modernity identified either with a "deep", indigenously rooted Latin America, or with a single, homogeneous social base such as a racially fused population, or with a cultural and religious cement of Catholic origin. All these tend to define modernity or its alternative on the basis either of the externality of the subject, or of a transcendental essentiality, with the result that they fail to reflect forms of social coexistence in Latin America that combine in a way that falls somewhere between confusion and creativity-the rational-scientific aspect, the expressivecommunicative aspect and the collective historical memory.

This is probably the newest axis of the collective action seen in Latin America over recent years. It is especially visible in the new methods of indigenous action, in the sociability and political redefinition of the young, and in movements like that of Chiapas that combine different dimensions, including the ethnic, socio-economic and political dimensions. ${ }^{21}$

\section{VII}

\section{Collective and political action}

When we speak of actors and civil society, the reality we now have to deal with is quite a complex one, since what seems to be taking place is a general weakening of collective action and of social actors and movements and an alteration in the landscape of social actors.

The current situation is one of: greater individualization in the behaviour and strategies of the peasant movement, which are associated with migration and drug trafficking in some cases, with the probable exception of the Landless Workers Movement in Brazil; State legitimation and institutionalization of women's movements; the orientation of settler movements, formerly associated with land seizures, towards issues of urban security; workers' struggles against economic and labour policies and for a renewal of State intervention, more than against capital; guerrilla movements that are less focused on taking power than on negotiating a place for themselves in the institutional sphere; students who are more concerned to defend their gains and interests than to transform the education system; human rights movements that are more sporadic or ad hoc; the strengthening of politico-electoral actions and of citizen participation, rather than large movements for radical social change. Lastly, the most significant development seems to be the shift by ethnic actors towards struggles for principles of identity and autonomy from the national State. ${ }^{22}$

The traditional actors have lost some of their social significance and are tending to become corporativized. Those that are emerging in response to new postauthoritarian issues have been unable to turn themselves into stable actors or a citizenry, but operate more in the capacity of publics or in ad hoc mobilizations. In situations like these, social actors as such are tending to be replaced by sporadic mobilizations and fragmentary, defensive actions, sometimes in the form of social networks that are significant but are not highly institutionalized and have little political representation, or by individual consumerism-type reactions or withdrawal. Another force, meanwhile, is that of individuals aggregated in the form of public opinion as measured by surveys and mediatized not by mobilizing or representative organizations but by the mass communications media.

\footnotetext{
${ }^{21}$ Escobar and Alvarez, eds. (1992), Eckstein (2001a) and Reyna (1995).

${ }^{22}$ For an overview, see Eckstein (2001a). Regarding ethnic movements, see Stavenhagen (2001).
} 
It is obvious that there are facets of the processes described which damage the quality of democratic life, by eroding the incentives for collective and political action, on the one hand, and by submitting the political process to pressures and bargaining by powerful corporate actors or to blackmail by large publics, de facto powers or the mass communications media, on the other. But it is also true that opportunities are opening up for more autonomous collective action and social actors.

The creation of actors in the style of the past can no longer be contemplated. It is unlikely that there can be a single subject or central Social Movement or social or political actor generating around itself a single field of tensions and contradictions that can link together the different principles and orientations of action arising from the axes of political democratization, social democratization, economic restructuring and identity and modernity.

Although it may well be that we are now seeing the end of an era characterized mainly by "inward" national development processes whose undisputed, unopposed agent was a mobilizing State, and the emergence of development processes that are caught up with transnationalized market forces, this does not mean that State action has lost its importance, but rather that changes are occurring in its organization and methods of intervention, and that its relations with other actors in society are being redefined.

Thus, and contrary to the optimistic or doomsday versions of globalization, the imperialism of the market or the resurgence of civil society, there is a paradox as regards the function of the State in a new socio-political model. If it is no longer possible to conceive of a State that is the exclusive unifier of social life, nor is it possible to dispense with State action to protect individuals and to create the spaces and institutions needed for significant actors to emerge independently of it. If the State and, in some cases, parties and the political class do not perform this function of re-creating the bases upon which social actors are formed, the social vacuum and crisis of representation will continue indefinitely.
All this means redefining the meaning of politics in democracy, because many of the criticisms levelled at recent democracies stem from a deeper questioning of the traditional forms of politics. Politics formerly had a double meaning in the social life of our countries. Firstly, the role of the State as the main engine of social development and integration meant that politics was seen as a way of gaining access to the State's resources. Secondly, politics played a fundamental role in giving meaning to social life and shaping identities, through projects and ideologies of change. This is why it was more of a mobilizing force and was more pervasive, ideological and confrontational than in other sociocultural contexts.

In the new situation created by the social, structural and cultural changes we have referred to, which are breaking up the unity of the society-polis, of the society built around the national State, the exclusive centrality of politics as the expression of collective action is tending to disappear. But it is acquiring a new, more abstract centrality, insofar as it has a responsibility to address itself to and create links among the different spheres of social life, without destroying their independence. Thus, there is less room for highly ideological, wilful or globalizing policies, but there is a demand being made on politics, the demand for "meaning", something that, on their own, market forces, the media world, particularisms or mere calculations of individual or corporate interest are unable to provide.

If the risk of traditional politics was ideologism, polarization and even fanaticism, the risk of today is banality, cynicism and corruption. As both traditional politics and authoritarian and neoliberal attempts to extirpate it have weakened, and as the inadequacies both of today's pragmatism and technocratism and of an exclusive reliance on civil society have become clear, the great task for the future is to rebuild the institutional space, the polis, in which politics regains its meaning as the link between strong, independent social actors and a State once again playing the role of development agent in a world that threatens to destroy national communities. 


\section{VIII}

\section{Parties and social actors}

Military authoritarianisms sought to destroy any form of political action, and their main targets were political parties and organizations. Although they did not achieve their aim and these played a key role in democratization, the task of building up strong party systems remained. In some cases where the party system was completely destroyed, the task is to build parties. In other cases, it is to establish party systems by breaking the monopoly of the hegemonic party or a traditional two-party system, while in others again it is to rebuild the relationship among society, social actors and the party system. In short, there are countries that will have to deal with all or some of these tasks. Each country has a different problem, but all are engaged in one way or another in a complex process whose objective is a stronger party system capable of controlling a State which itself needs strengthening.

In general terms, there are at least three aspects of the party system that will have to be reviewed, to ensure that parties can perform their tasks of political leadership and intermediation between the world of social actors and the State.

The first need is for legislation to ensure that parties have status and financing, while at the same time establishing appropriate public controls over them. The second is for representation of the new types of fragmentation and conflict in society: if party systems are really to be a reformed expression of social demand in all its diversity, there will have to be innovation in the constitution of institutional spaces where they can encounter other manifestations of social life, as is illustrated by the legislation on popular participation in Bolivia, to cite one example. A third aspect, which will also determine the future of political parties, will be the ability to form majority coalitions to govern. As competitive multi-party systems are created, the most likely outcome is that there will be no party that can win a majority by itself and provide effective, representative government. This is already the central issue in Latin American party politics, and will continue to be so over the coming decades.
If party leadership appears to be challenged "from above" by the weakening of the State as a referent for social action, and "from the middle" by the problems inherent in reorganizing the party system, it can be said that, "from below", new social organizations appear to be reducing its role in society.

Among these, there is the so-called "third sector", constituted by NGOs, whose main role in the reconstruction of society is that of linking democratic elites of a professional, technocratic, political or religious nature with popular sectors, especially at times when politics is repressed by authoritarianism or society is atomized by the economic transformations imposed by the logic of the market. Actors of this type perform different roles in this respect. Firstly, they provide material support and organizational space to the poorer or weaker sections of society, particularly the most militant ones, when they cannot take direct political action. Secondly, they link these sectors with national and international human rights, economic, religious and political institutions through a cadre of social leaders and activists belonging to the social and political world, thereby providing a wider space for participation than the parties. Thirdly, some of them at least are forums for learning about what is happening in society and for devising social and political ideas and projects for change, so that they become centres of thought or leaders of public opinion.

But we need to avoid taking a naïve or exaggeratedly optimistic view of the relations between NGOS and other types of organizations or institutions such as political parties. The fact is that NGOS sometimes tend to replace political actors and promote their own particular interests, while at other times they tend to radicalize social and political action by calling for a type of direct democracy that may leave no room for institutional determinants. In turn, political parties cannot always resist manipulating these organizations, and tend to rule out actions that do not yield immediate political gains. Thus, the process of learning and mutual understanding takes a long time. 


\section{IX}

\section{Conclusion: the new matrices of social action}

What we have tried to suggest in this work is that we are faced with new forms of collective action that depend more on axes and processes of historical action than on structural positioning, although this does not mean that there are no major resistance and defensive movements that resemble the more traditional forms characteristic of the national-popular matrix. Even in these movements, however, there is a significant admixture of the new principles and forms of collective action.

As regards the matrix that shapes social actors (the relationship among the State, representation, the regime and the socio-economic and cultural base), with the breakdown of a particular relationship between the State and society which we have termed national-popular, and in which the political dimension was the most important in shaping social actors, what we are seeing is the disappearance of a central or structuring principle in the formation of the generality of these actors, who are coming to define themselves in relation not so much to a central social movement or project as to different axes constituted by political and social democratization processes, economic restructuring and the affirmation of identities and models of modernity.

As regards the configurative matrix (combination of levels and dimensions and of spheres and ambits in which the action or actor is situated), there would seem to be a tentative and ambiguous shift away from actors that are basically economic and political and centred on the historico-structural level of societies and towards actors that are defined socioculturally and by reference to the worlds of life (subjectivity) and to organizational and institutional instrumentalities.

This is not the place to analyse recent manifestations of collective action which, because of their complexity, would seem to contradict this analytical framework. Nonetheless, all of them (urban explosions such as those of Caracas or Ecuador and Bolivia, movements with a large ethnic component, such as that of Chiapas, citizen participation movements such as those of Peru, pickets in Argentina, workers' strikes again company closures, teachers' and public employees' movements, the Landless Workers
Movement in Brazil, human rights movements in Central American countries and the Southern Cone, students in Mexico and Chile and guerrillas in Colombia, to cite just some very well known examples), despite the huge differences between them, can be studied from the viewpoint sketched out here, i.e., as manifestations of the survival, breakdown and recomposition of this double matrix in a context of globalization and transformation of the development model and of institutional frameworks.

Changes in civil society have given rise to new types of demands and principles of action that cannot be captured by the old struggles for equality, liberty and national independence. The new issues, which are concerned with daily life, interpersonal relations, personal and group achievement, aspirations to dignity and social recognition, the sense of belonging and social identities, are situated rather in the dimension of what have been termed "worlds of life" or intersubjectivity, and cannot be replaced by the old principles. They no longer belong exclusively to the private domain and they exercise their demands in the public sphere. This new dimension does not replace the old ones, of course, but it brings more diversity and complexity to social action.

The main change that this dimension is introducing into collective action, apart from the fact that the old forms of organization (unions, parties) seem to be inadequate for these particular purposes, is that it provides a very diffuse principle of opposition and is based not only on confrontation but also on cooperation. Consequently, it is not directed against a clear opponent or antagonist, as was generally the case with traditional social struggles.

Whereas in the past we saw a central subject in search of social actors and movements that would embody it, the current situation seems to be more one of particular movements and actors seeking a central constitutive subject or principle.

What would seem to be the most likely outcome in the near future is a variety of forms of struggle and mobilizations that are more autonomous, shorter, less politically oriented, institution-related rather than extra-

THE TRANSFORMATION OF COLLECTIVE ACTION IN LATIN AMERICA • MANUEL ANTONIO GARRETÓN M. 
institutional, and more oriented towards sectoral inclusion, partial modernizations and gradual democratization and social integration than towards radical, comprehensive change. The substance of these mobilizations will probably be split between concrete demands for inclusion and the search for a distinguishing meaning and identity in the face of the universalization of a "modernity" identified with the forces of the market and its agents. If these demands are not met, it is very likely that there will be some sudden explosions and rebellions, or a withdrawal into apathy, individualism or communitarianism, or some combination of these, rather than a resurgence of coherent, stable actors.
In summary, while it is true that there can be no return to traditional collective action (although many of its elements may survive), there is potential in the new situation, as identified in other sections, for a redefinition of citizenship and a new way of thinking about collective action. What still remains to be resolved is the relationship between these manifestations and political life. There seems to be a vital need for institutionalized spaces in which traditional forms can be expressed along with emerging ones. As we have said, the paradox is that this can only happen if the initiative comes from politics and political actors, however problematic this may be, and however much it may seem to go against the tide.

\section{Bibliography}

Barba, C., J.L. Barros and J. Hurtado (comps.) (1991): Transiciones a la democracia en Europa y América, Mexico City, Latin American Faculty of Social Sciences (FLACSO)/University of Guadalajara.

Bayardo, R. and M. Lacarrieu (1999): La dinámica global/local. Cultura y comunicación: nuevos desafios, Buenos Aires, Ediciones Ciccus.

Calderón, F. (ed.) (1986): Los movimientos sociales ante la crisis, Buenos Aires, Latin American Social Sciences Council (CLACSO).

Calderón, F. and J.L. Reyna (1995): La irrupción encubierta, in J.L. Reyna (comp.), América Latina a fines de siglo, Mexico City, Fondo de Cultura Económica (FCE).

Castells, M. (1997): La era de la información. Economía, sociedad y cultura, Madrid, Alianza Editorial.

Cavarozzi, M. (1996): El capitalismo politico tardio y su crisis en América Latina, Buenos Aires, Homo Sapiens Ediciones.

Chonchol, J. (2000): ¿Hacia dónde nos lleva la globalización?, Santiago, Chile, LOM Ediciones.

Colegio de México (1994): Transformaciones sociales y acciones colectivas. América Latina en el contexto internacional de los noventa, Mexico City.

Collier, D. (ed.) (1979): The New Authoritarianism in Latin America, Princeton, New Jersey, Princeton University Press.

Corradi, J., P. Weiss and M.A. Garretón (eds.) (1992): Fear at the Edge. State Terror and Resistance in Latin America, Berkeley, California, California University Press.

Dubet, F. and D. Martuccelli (1998): ¿Dans quelle société vivonsnous?, Paris, Seuil.

Dubet, F. and M. Wieworka (1995): Penser le sujet, Paris, Fayard.

Durston, J. (2000): ¿Qué es el capital social latinoamericano?, Santiago, Chile, ECLAC, July.

Eckstein, S. (2001a): Epílogo ¿Qué ha sido de todos los movimientos? Los movimientos sociales latinoamericanos en vísperas del nuevo milenio, in S. Eckstein (coord.), Poder y protesta popular. Movimientos sociales latinoamericanos, Mexico City, Siglo XXI Editores.

(2001b): Poder y protesta popular en América Latina, in S. Eckstein (coord.), Poder y protesta popular. Movimientos sociales latinoamericanos, Mexico City, Siglo XXI Editores.
Eckstein, S. (coord.) (2001c): Poder y protesta popular. Movimientos sociales latinoamericanos, Mexico City, Siglo XXI Editores.

ECLAC (Economic Commission for Latin America and the Caribbean) (1992): Equity and Changing Production Patterns: An Integrated Approach, LC/G.1701/Rev.1-P, Santiago, Chile. (2000a): La brecha de la equidad. Una segunda evaluación, LC/G.2096, Santiago, Chile.

(2000b): Equidad, desarrollo y ciudadania, LC/G.2071/ Rev.1-P, Santiago, Chile.

Escobar, A. and S. Alvarez (eds.) (1992): The Making of Social Movements in Latin America. Identity, Strategy and Democracy, Boulder, Colorado, Westview Press.

Ffrench-Davis, R. (2000): Macroeconomía, comercio y finanzas. Para reformar las reformas en América Latina, Santiago, Chile, ECLAC/McGraw Hill.

Filgueira, C.H. (2001): La actualidad de viejas temáticas: sobre los estudios de clase, estratificación y movilidad en América Latina, Políticas sociales series, No. 51, Santiago, Chile, ECLAC.

Flores Olea, V. and A. Mariña (1999): Crítica de la globalidad. Dominación y liberación en nuestro tiempo, Mexico City, Fondo de Cultura Económica (FCE).

García Canclini, N. (1980): Culturas híbridas. Estrategias para entrar y salir de la modernidad, Madrid, Grijalbo.

(1999): La globalización imaginada, Mexico City, Fondo de Cultura Económica (FCE).

Garretón, M.A. (1994): La faz sumergida del iceberg. Ensayos sobre la transformación cultural, Santiago, Chile, Centro de Estudios Sociales (CESOC).

(1995a): Hacia una nueva era politica. Estudio sobre las democratizaciones, Santiago, Chile, Fondo de Cultura Económica (FCE).

(1995b): Social movements and the process of democratization. A general framework, International Review of Sociology, vol. 6, No.1, Rome.

(1997a): “¿En qué sociedad vivi(re)mos? Tipos societales y desarrollo en el cambio de siglo", in H. González and H. Schmidt (eds.), Democracia para una nueva sociedad. Modelo para armar, Caracas, Editorial Nueva Sociedad. 
(1997b): Revisando las transiciones democráticas en América Latina, Nueva sociedad, No. 148, Caracas, Editorial Texto, March-April.

(1998): A new socio-historical 'problématique' and sociological perspective, Sociologie et sociétés, vol. 30, No.1 (Special Issue, The Second Wind of Sociology), Montreal, Quebec, University of Montreal, Department of Sociology.

(2000a): Politica y sociedad entre dos épocas. América

Latina en el cambio de siglo, Rosario, Argentina, Ediciones Homo Sapiens.

(2000b): La sociedad en que vivi(re)mos. Introducción sociológica al cambio de siglo, Santiago, Chile, LOM Ediciones.

(2001a): Movilización popular bajo el régimen militar en Chile. De la transición invisible a la democratización política, in S. Eckstein (coord.), Poder y protesta popular. Movimientos sociales latinoamericanos, Mexico City, Siglo XXI Editores.

(2001b): Cambios sociales, actores y acción colectiva en América Latina, Políticas sociales series, No. 56, Santiago, Chile, ECLAC.

Garretón, M.A. (ed.) (1999): América Latina: un espacio cultural en el mundo globalizado, Bogotá, Convenio Andrés Bello.

Germani, G. (1965): Politica y sociedad en una época de transición. De la sociedad tradicional a la sociedad de masas, Buenos Aires, Editorial Paidós.

Gohn, M.G. (1997): Teoría dos movimentos sociais. Paradigmas clássicos e contemporáneos, São Paulo, Ediçoes Loyola.

Hartlyn, J. (2000): Contemporary Latin America Democracy and Consolidation. Unexpected Patterns, Re-elaborated Concepts, Multiple Components, Washington, D.C., Woodrow Wilson International Center for Scholars, Latin American Program.

Hengstenberg, P., K. Kohut and G. Maihold (eds.) (1999): Sociedad civil en América Latina: representación de intereses y gobernabilidad, Caracas, Editorial Nueva Sociedad.

ILADES (Latin American Institute of Social Theory and Social Studies) (1996): Identidad y modernidad en América Latina, Revista persona y sociedad, vol. 10, No.1, Santiago, Chile, April.

Jelin, E. and E. Herschberg (eds.) (1995): Constructing Democracy. Human Rights, Citizenship and Society in Latin America, Boulder, Colorado, Westview Press.

Levine, D. and S. Mainwaring (2001): Religión y protesta popular en América Latina: experiencias contrastantes, in S. Eckstein (coord.), Poder y protesta popular. Movimientos sociales latinoamericanos, Mexico City, Siglo XXI Editores.

López, S. (1997): Ciudadanos reales e imaginarios. Concepciones, desarrollo y mapas de la ciudadanía en el Perú, Lima, Instituto de Diálogo y Propuestas.

McAdam, D., J. McCarthy and M. Zald (1998): Social movements, in N. Semelser (ed.), Handbook of Sociology, San Francisco, California, Sage Publications.

Melucci, A. (1996): Challenging codes. Collective Action in the Information Age, Cambridge, Massachusetts, Cambridge University Press.

Moreira Alves, M.H. (2001): Las alianzas entre clases que se forjaron en la oposición a los militares en Brasil, in S. Eckstein (coord.), Poder y protesta popular. Movimientos sociales latinoamericanos, Mexico City, Siglo XXI Editores.
Navarro, M. (2001): Lo personal es político: las Madres de la Plaza de Mayo, in S. Eckstein (coord.), Poder y protesta popular. Movimientos sociales latinoamericanos, Mexico City, Siglo XXI Editores.

Nun, J. (1989): La rebelión del coro, Buenos Aires, Ediciones Nueva Visión.

O’Donnell, G. (1999): Contrapuntos, Buenos Aires, Editorial Paidós.

(2001): Reflections on contemporary South American democracies, Journal of Latin American Studies, No. 33, Cambridge, Massachusetts, Cambridge University Press.

Portes, A. (1998): El neoliberalismo y la sociología del desarrollo: tendencias emergentes y efectos inesperados, Perfiles latinoamericanos, year 7, No. 13, Mexico City, flacso.

Reyna, J.L. (1995): La irrupción encubierta, in J.L. Reyna (comp.), América Latina a fines de siglo, Mexico City, Fondo de Cultura Económica (FCE).

Reyna, J.L. (comp.) (1995): América Latina a fines de siglo, Mexico City, Fondo de Cultura Económica (FCE).

Slater, D. (ed.) (1985): New Social Movements and the State in Latin America, Amsterdam, The Netherlands, Centre for Latin American Research and Documentation (CEDLA).

Smith, P.H. (1995): Latin America in Comparative Perspective. New Approaches to Methods and Analysis, Boulder, Colorado, Westview Press.

Smith, W., C. Acuña and E. Gamarra (eds.) (1994): Latin American Political Economy in the Age of Neo-Liberal Reform: Theoretical and Comparative Perspectives for the 1990's, New Brunswick, Transactions Publishers.

Sosa, R. (1996): América Latina y el Caribe, Perspectivas de su reconstrucción, Mexico City, Asociación Latinoamericana de Sociología (ALAS), National Autonomous University of Mexico (UNAM).

Stavenhagen, R. (1995): A la sombra del desarrollo: campesinos e indígenas en la crisis, in J.L. Reyna (comp.), América Latina a fines de siglo, Mexico City, Fondo de Cultura Económica (FCE).

(2000): Derechos humanos de los pueblos indigenas, Mexico City, Comisión Nacional de Derechos Humanos.

(2001): La cuestión étnica, Mexico City, El Colegio de México.

Touraine, A. (1973): Production de la société, Paris, Seuil. (1984): Le retour de l'acteur, Paris, Fayard.

(1987): Actores sociales y sistemas políticos en América Latina, Santiago, Chile, Programa Regional del Empleo para América Latina y el Caribe (PREALC).

(1989): Política y sociedad en América Latina, Madrid, Espasa Calpe.

(1992): Critique de la modernité, Paris, Fayard.

(1997): Pourrons-nous vivre ensemble? Egaux et différents, Paris, Fayard.

(2000): La recherche de soi. Dialogue sur le sujet avec F. Khosrokhavar, Paris, Fayard.

Wright, E.O. (1997): Class Counts. Comparative Studies in Class Analysis, Cambridge, Massachusetts, Cambridge University Press.

Zermeño, S. (1978): México: una democracia utópica. El movimiento estudiantil del 68, Mexico City, Siglo XXI. 